\title{
An Early Modern Mass Medium: The Adventures of Cartouche in Dutch Penny Prints (1700-1900)
}

\author{
Jeroen Salman, Utrecht University
}

In the eighteenth century, Dutch penny prints were circulated in the hundreds of thousands to every corner of the country and throughout all levels of society. As a cheap and widespread genre, these prints bridged the gap between high and low culture, between literature and folk narratives, between the arts and popular imagery and between the city and the countryside. Given this medium's social reach, unique format and varied content, the intriguing question arises of what penny prints can teach us about the popularization of knowledge, literature and news during this time. ${ }^{1}$ Until recently, however, penny prints have hardly been studied in the wider perspective of eighteenth- and nineteenthcentury social-cultural history. The studies that deal with cheap material like penny prints often underline its controlling and social conformist character, ${ }^{2}$ although others stress its more interesting deregulating character. ${ }^{3}$ In this article I want to argue that penny prints should not be seen as just part of a commercialized, conformist mass culture, but as a form of social resistance and protest as well. Furthermore, I want to oppose the idea that popularization processes in the literary field, in which these penny prints played a crucial role, were only linear and one-dimensional. The production and reception of this material often proceeded in a more cyclical, dynamic and sometimes even ambiguous fashion. To achieve these new insights, I will use a combination of media and cultural historical approaches (Henry Jenkins, John Fiske, Andrea McKenzie, Peter Linebaugh) and an anthropological perspective (Eric J. Hobsbawm).

To discover to what extent historical popular print culture can be associated with modern mass media, we will discuss the seminal work

Cultural History 7.1 (2018): 20-47

DOI: $10.3366 /$ cult.2018.0157

(C) Edinburgh University Press www.euppublishing.com/cult 
Convergence Culture: Where Old and New Media Collide, by Henry Jenkins. ${ }^{4}$ In this work Jenkins describes how new media technologies have transformed popular culture in our modern society. A second approach is grounded in the work of another media scholar, John Fiske, who published Understanding Popular Culture. ${ }^{5}$ Fiske stresses the capacity of popular culture to resist and evade dominant cultural forces. Both Jenkins's and Fiske's ideas are relevant for our inquiries because they raise the intriguing issue as to whether Dutch penny prints were part of a growing mass culture dominated and produced by a cultural elite, or whether this medium can be viewed as a manifestation of a cultural counterforce orchestrated by the lower classes or cultural intermediaries. ${ }^{6}$ A third, more anthropological approach focuses on the role of these penny prints in the identity-shaping process of folk heroes and literary characters. Were penny prints indeed less suitable than pamphlets and periodicals for social protest and political discourse? The anthropological perspective and Fiske's perspective will be supplemented with relevant historical research on the connection between the British, eighteenth-century criminal biography and social critique. $^{7}$

Because banditism is a crucial topic in relation to debates about popular forms of eighteenth- and nineteenth-century social protest, I have decided to focus on the story of the French criminal and hero Louis Dominique Cartouche. Cartouche was born in 1693 in the Paris district Courtille and was executed on 27 November 1721 in Paris at the age of twenty-eight. The multiple representations of Cartouche - spanning pamphlets, songs, biographies, prints, paintings and movies - can be understood as a significant cultural phenomenon. I have studied the translations, adaptations, media, genres and forms in which Cartouche's story was represented in Europe, with a strong focus on penny prints, in order to ascertain the reason for his widespread appeal and his conformist as well as rebellious function in popular culture. Because the story of Cartouche has strong connections with the emergence of the eighteenth-century narratives on British highwaymen and their appearance in popular genres such as pamphlets and dying speeches, I will contrast my findings with some crucial studies in this field. ${ }^{9}$

The first section of this article discusses the three theoretical approaches used and relevant debates on popular print culture in greater detail. Then I zoom in on Cartouche to discuss the popularization process of his story while taking into account the role of the medium (penny prints), the social-cultural background and the representations of Cartouche. 


\section{Cultural History}

\section{Cartouche, banditism and popular narratives}

A key concept to distinguish the different functions of penny prints is popular culture. This concept encompasses a broad and multifaceted field of study with a long tradition of fierce debate. While I will not recount all the positions and arguments here, I focus on the discussion of popular culture versus mass culture. This distinction, made by Fiske among others, is not relevant only for modern societies but can also be applied to earlier centuries. Fiske states that the process of cultural production is strongly related to the distribution of power within society. Culture-making is inherently political and controversial. This implies that some groups have more power to spread their ideologies than others. In his view, mass culture represents and supports the mainstream beliefs of the dominant elites in a society. In contrast, popular culture, according to Fiske, is the domain of social groups who are subordinated and disempowered by the social system, such as women, people of colour and the poor. These groups use the media and products of the dominant system - like television, books, magazines, clothes and even language - but only in a way that serves their own interests. ${ }^{10}$

Fiske distinguishes two strategies within popular culture to oppose the dominant cultural industry: resistance and evasion. Resistance refers to alternative forms of reading that serve the interests of the subordinated group rather than the elites. The creative reading process that is connected to this sort of pleasure affirms or empowers people. Evasion involves strategically escaping from social control. This social control can be imposed through norms, social mores, taboos and laws that regulate how we are permitted to conduct ourselves. ${ }^{11}$

Fiske's theories have been supplemented by Jenkins's notions on popular culture; the latter provides more tools that can be applied to long-term developments in the penny prints' production and reception. Jenkins states that our modern culture is a 'convergence culture', characterized by 'the flow of content across multiple media platforms, the cooperation between multiple media industries, and the migratory behaviour of media audiences who will go almost anywhere in search of the kinds of entertainment experiences they want'. ${ }^{12}$ The first two criteria point to the power of large companies and media magnates in the cultural industry, who bring together film studios, television stations, publishing houses, music production and game development. This grants them the power to distribute the same content over multiple media platforms. From Fiske's perspective, these two forms of convergence can be seen as manifestations of mass culture. The third criterion mentioned by Jenkins - the migratory behaviour of audiences-brings into play the same audience creativity that 
Fiske suggests in his definition of popular culture. Jenkins believes in the autonomy of the public in seeking out entertainment, and he stresses their creative and productive attitude towards cultural consumption. For example, fans of Star Wars upload home-made adaptations, while fans of Harry Potter also expand their favourite story by creating new online characters and plots based on the original books. ${ }^{13}$

This tension between mass culture and popular culture is especially relevant for this examination of Dutch penny prints given how one can compare historical data from the publishing houses - which dominated the mass production of this material - with the creative appropriation of these materials by many buyers, readers and listeners. Yet when conducting this study we were confronted with a lack of sources from the eighteenth and nineteenth centuries, especially with regard to the field of reading experiences. In this historical context, how can we know whether strategies such as resistance and evasion - the rebellious function - actually took place? The solution to this problem can be found in one of the genre's characteristics: the longevity and flexibility of penny prints. Print publishers tried to reproduce the same stories, using the same woodblocks, for as long as possible. Yet they did need to change the texts, and sometimes the images, to reflect changing tastes, opinions, needs and audiences. In such adaptations - where the changes were minor and gradually implemented - and in unchanged reproductions, the voice of the consumer resonates. It can be said that penny prints themselves embody the dominant culture as well as the counterculture.

In reconstructing the publication history of Cartouche, I therefore focused on what the different adaptations can tell us about the motives, wishes and strategies of all the actors involved: engravers, translators, editors, publishers, booksellers, street sellers, buyers and, of course, readers. In this sense Cartouche is a good case to study because the story remained in print for so long and was adapted to multiple genres, aimed at many different social categories of readers.

Whereas the works of Jenkins and Fiske point towards the media-theoretical and social aspects of the penny print, anthropologists (and criminal historians) like Eric J. Hobsbawm, Anton Blok, Florike van Egmond and Andrea McKenzie point out the ideological function of the penny narratives. When dealing with Cartouche in particular, we are confronted with questions about the role of bandits and highwaymen in urban and rural societies and about their literary representations and capacity for identity formation. ${ }^{14}$ Cartouche has become the subject of a continuing debate about the phenomenon of the 'social bandit'. This concept was coined by Hobsbawm in his monograph Bandits, where he stated, 'The 18th century is the golden age of social banditism. The city 


\section{Cultural History}

based Cartouche was a criminal, who was adapted into the social-bandit pantheon like Dick Turpin and Schinderhannes. ${ }^{, 15}$

Hobsbawm's definition of social banditry was criticized by Blok, who rejected the view of the rural bandit as a representative of the poor peasantry, avenging social injustice. The bandit was social in the sense that he depended on a wider circle of people, according to Blok, and because he needed protection in order to function. Yet this protection was not automatically provided by the poor or by representatives of his own social class. This much-needed protection could also be granted by the political elite, which was certainly true for Cartouche. Cartouche was successful in large part because of the wide network of soldiers, local administrators, noblemen and women of high birth who helped to protect him and shared in the loot. Blok hypothesizes, 'The more successful a man is as a bandit, the more extensive the protection granted him. ${ }^{16}$ This could have been an important basis for the enduring popularity of the narrative as well.

Blok and Hobsbawm also disagree on the function of the myths and legends surrounding the bandit, like those about Cartouche. Blok believes that these myths fulfil the peasants' need to position the bandit as a hero fighting for social justice. Hobsbawm, however, does not see a great distinction between myth and reality: 'My view is that the myth cannot be entirely divorced from the reality of banditry. ${ }^{17}$ In his view, the bandit's image functions as part of his actual societal role. The people considered some bandits good and others bad. This implies, according to Hobsbawm, that there must be some relation between the real behaviour of the bandit and the myth. It is also important to distinguish between the myths surrounding bandits who were personally known and the myths that are based on information from a distant place and time. Following Hobsbawm's reasoning, the Dutch nineteenth-century myth of Cartouche should be less accurate than the myths that circulated about Cartouche in Paris from the 1720 s onwards. ${ }^{18}$ This is a point I return to later in greater detail.

Egmond labels Cartouche and his German equivalent, Schinderhannes (who appeared somewhat later), as 'noble bandits'. ${ }^{19}$ She stresses that they were often positively represented and that this appealed not so much to the lower (rural) classes but mostly to the middle classes, who could personally identify with these entrepreneurs and adventurers. However, Egmond does make an exception for cheaper genres like songs and complaints. These forms were more negative and linked Cartouche with the devil, who is said to have inspired him. ${ }^{20}$ Yet it is striking that in her analysis Egmond does not explicitly refer to penny prints, one of the main categories of cheap print in those days. 
Thus, the question remains whether or not penny prints were as negative and socially conformist as the songs and complaints to which Egmond refers. $^{21}$

Whereas in France, Germany and the Netherlands Cartouche is often seen as the icon of eighteenth-century social banditism, in England several (fictional and non-fictional) highwaymen - Jonathan Wild, Jack Sheppard, Paul Lewis, Captain Macheath and so on - served that purpose $^{22}$ In an article on social satire and the criminal biography, McKenzie states that the English highwayman, more than the rogue in earlier literature, became a paragon of social critique in the eighteenth century. This robber selected his victims from the wealthy classes and was in many ways a gentleman himself. In her view, and contrary to Egmond, the most subversive messages were expressed in the so-called dying (execution) speeches, one of the most popular forms of street literature in eighteenth-century England. ${ }^{23}$ This makes a further exploration of a Dutch equivalent, the penny prints, and its representation of Cartouche even more relevant and urgent.

\section{Cartouche in Dutch literature}

The success of the story of Cartouche in France and elsewhere can, in part, be attributed to the quality of the anonymous biography Histoire de la vie et du process du fameux Louis-Dominique Cartouche ('History of the life and trial of the famous Louis-Dominique Cartouche'), which probably first appeared in $1722 .{ }^{24}$ It was not only well written but remarkably precise in sketching the difficult social circumstances that this Parisian criminal faced. Given the many references to his life in works by Denis Diderot, Voltaire and Jean-Jacques Rousseau, it is assumed that Cartouche was seen as an enlightened sceptic and freethinker. Other experts state that what impressed so many people - from high to low - was Cartouche's flamboyant appearance and strong personality. ${ }^{25}$

The 1722 biography contains a very meticulous description of the motivations, dealings and deeds of the criminal Cartouche. Like numerous soldiers involved in the War of the Spanish Succession, Cartouche was demobilized from the French army after the Peace of Utrecht in 1713. Cartouche's biographer argues that many of these former sons of farmers should have been offered jobs or given other forms of support by the government. Instead, most had to resort to begging or criminal activities to survive. Cartouche became the captain of one such gang composed in part of ex-soldiers, amongst others. One recurring episode throughout many of the biography's editions is a tale where Cartouche is disguised as a merchant. He then gets hold of a bill of exchange and cashes this with a local banker. Equally important 
is a scene in which Cartouche decides to leave Paris, having been warned by a friend of his imminent arrest. From Paris he travels to Orleans, and from there onwards to Bar sur Seine. In this village he changes his identity to Charles Bourguignon. After leading a quiet life for some time, he eventually decides to return to the capital, which ultimately leads to his downfall. In Paris he is betrayed by one of his own men and ends up in Chatelet prison.

This, however, is not the end of Cartouche's story. Although imprisoned, he miraculously escapes via the sewer - which is yet another iconic scene - but is caught again in the house next door (betrayed this time by a barking dog). The focus on 'gaol-breaking' is not just an incident but can be seen as a more general feature of criminal biographies (including the English ones), symbolizing the pursuit of (social) freedom. ${ }^{26}$ From then on, Cartouche is heavily chained and closely guarded. While in prison Cartouche retains his attractiveness for the people. He is visited by all sorts, but most frequently by women from the higher classes. ${ }^{27}$ Some of them beg him to show remorse, betray his fellow gangsters and ask his confessor to forgive him. Yet Cartouche does not falter. Finally, the moment comes, and Cartouche is convicted of robbery and murder. There seems to be no escape from execution by means of the wheel, an eighteenth-century instrument of torture. Once on the scaffold in front of a mass audience, and face to face with his executioner, the villain realizes that this time his fellow gangsters are not going to help him to escape. This is the turning point that leads to Cartouche's confession and a plea for absolution. Although his conscience is now clean, it does not save him from a cruel execution. He is beaten to death and, after that, exposed to the audience in an anatomical theatre as a final, ultimate humiliation.

The biography of Cartouche became a bestseller across Europe and, together with the first theatre plays (comedies) based on the exciting life of Cartouche, formed the basis for a broad range of popularizations across different genres and media. In particular, the comedies are important here because they functioned as an intermediary between the biography and the penny prints. Considering the eventfulness of his life, it is not surprising that Cartouche fuelled the imaginations of many playwrights. About eight French plays were written about his life and deeds, many of which were translated into other European languages.

Long before Cartouche's arrest (on 14 October 1721) Marc Antoine le Grand had written a play entitled Cartouche, ou l'Homme imprenable ('Cartouche, the unstoppable man'). As it turned out, the Paris magistrate did not permit this play to be staged, fearing it would harm the reputation of the local police. Indeed, the play's message was that 
the Paris police were weak and powerless and therefore unable to catch this criminal. The tables turned when Cartouche was actually arrested and imprisoned in October 1721. It was then that le Grand's play was performed and published, albeit under another, less controversial title: Cartouche, ou les Voleurs ('Cartouche, or the robbers'). Le Grand, who played the leading role, claimed that he had visited Cartouche several times in the Chatelet prison to study his gestures, speech and behaviour. ${ }^{28}$ The comedy is about a rich merchant named Oronte, who lost not only his money but also his reputation and future wife. He fell into a trap set up by Cartouche and his friends. Although the villain was ultimately punished and social order restored, the audience probably felt sympathy for this lower-class criminal and animosity towards the rich, arrogant merchant Oronte. This is further supported when, in the end, the poor lover Valère (not Oronte) is allowed to marry Isabelle. In that sense, this telling clearly contains elements of what Fiske would describe as social protest and resistance. The play appears to have been a great commercial success, and the story goes that le Grand offered the prisoner a share in the revenues, which totalled 100 French crowns. ${ }^{29}$

The parallels with the British highwayman Captain Macheath in John Gay's play The Beggar's Opera are striking: not only is the narrative similar, but Macheath, just like Cartouche, gained public sympathy and became a symbol of social critique. First performed in 1728, Gay's play was embraced by a broad audience and condemned by moralists and the political elite. Although Macheath was a fictional figure, he was probably based on a real criminal, such as James Garrick or Jack Sheppard.$^{30}$ For the contemporary public, this distinction was irrelevant.

A number of French publications on Cartouche were swiftly translated into other European languages, including Dutch. This implies that the story was a hit in France from the start, and that this did not go unnoticed in the rest of Europe. The biography was translated into Dutch ('t Leven van den wereldberuchten kapitein der moordenaren Louis Dominique de Cartouche, 'The life of the notorious and widely known captain of murderers Louis Dominique Cartouche') and was published by Reinier Boitet in Delft before or during 1722. The publisher's preface is notable because it adds to the image of this story as an indictment of injustice and corruption. Boitet mentions that during Cartouche's final confession, a lot of accomplices were mentioned and that those people moved in Paris's higher circles. Boitet explained that this juicy bit of information was not in this first part of the biography but would be revealed in a second part (which never appeared). ${ }^{31}$ This Dutch translation contains several engravings depicting the most important events in Cartouche's life. 
In total, at least nine editions of the Dutch biography appeared during the eighteenth century, and each edition became smaller and cheaper (with woodcuts replacing engravings), implying an increasing lower-class audience. ${ }^{32}$ An important turning point occurred in 1773 in a cheap edition published by Barent Koene. This edition contained a preface written by Gysbert Tysens with a moralistic verse stating that the criminal Cartouche was rightly punished owing to all of his horrific, evil deeds. ${ }^{33}$ This more direct rejection of his actions fits with the analyses of Egmond, who argues that popular material about Cartouche largely portrayed him as an evil villain. I think, however, that this changing perception was not just the result of the popularization process but can be seen as part of a growing, broader (European) resentment against the social bandit after 1750. In England, for example, writers started to reject the gentleman robber or highwayman as a social critic and began to ridicule his pretensions. ${ }^{34}$

The French comedy Cartouche, ou les Voleurs by le Grand was translated into Dutch by Tysens as Cartouche of de rovers ('Cartouche or the robbers') and published by Johannes van Leeuwen in Amsterdam in 1722. A second Dutch translation, by Charles Sebille, appeared under a different title, but with the same content. Sebille's translation was published by Willem Barents in 1722 under the Dutch title De schelmeryen van Cartouche ('The villainies of Cartouche'). ${ }^{35}$ This translation was also published by Jacobus van Egmont in Amsterdam in 1722, but with a slightly different title: Cartouche, of De Dieven: Blyspel ('Cartouche, or the thieves: A comedy') ${ }^{36}$ Interestingly, this publication concludes with a list of books that were also available in van Egmont's shop, including penny prints. ${ }^{37}$ A third translation appeared in 1732, produced by the Dutch playwright Pieter Langendijk under the name De bedriegery van Cartouche, of de Fransche roovers. Blyspel ('The deceit of Cartouche, or the French robbers: A comedy') for Amsterdam theatre. ${ }^{38}$ The translation does not differ much from the original, although the names were made more Dutch-sounding than in Tysens's version. These translations demonstrate how immensely popular the figure of Cartouche was throughout the entire eighteenth century. They also reveal that the politically and socially controversial messages contained within these works apparently did not obstruct their dissemination. Perhaps this can be attributed to the fact that the play was presented as a comedy and not as a tragedy. Although the crimes Cartouche committed were severe, audiences probably did not take the play and its social critique too seriously.

The French plays led not only to (free) translations but also to the production of creative adaptations, as happened in Italy. Shortly after the staging of le Grand's play, an Italian version of the play was written by 
Luigi Riccoboni, Arlequin Cartouche ('The harlequin Cartouche'). Instead of three acts, this work contained five and had a more burlesque flavour (as indicated by the title). This play was performed by the Comédie-Italienne in 1721 but did not result in any form of subsequent publication. Nevertheless, translations into Dutch and German did appear in print in $1722 .{ }^{39}$

The mix of genres that portrayed the life and deeds of Cartouche represented both low and high culture. One example from the higher end of the artistic spectrum is the classic epic Cartouche, ou le vice puni ('Cartouche, or wickedness punished'), written by Nicolas Racot de Grandval (1676-1753) and published in $1725{ }^{40}$ It contains many references to classical texts (i.e. the Odyssey, the Aeneid). In this work Cartouche even justifies his own evil conduct by referring to mythological figures like Prometheus - who stole fire from the heavens. According to the conventions of the time, Grandval incorporates magical powers. For example, when Cartouche must flee Paris, the goddess Laverna helps him fly to Bretagne. The social message conveyed by Grandval is one that condemns the higher classes, merchants, doctors and lawyers for suppressing the ordinary people and stealing their money. Still, the poem includes light-hearted passages as well. Grandval states that Cartouche dedicated half of his time to Mars (crime) and the other half to Venus (love), although the latter goddess was represented by prostitutes. As an appendix to the epic, a slang dictionary of 'thief language' was even included. Grandval's poem was translated into Dutch as Cartouche, of the gestrafte Booswigt ('Cartouche, or the punished villain') and published in 1731 by the Amsterdam-based book seller Johannes de Ruyter. De Ruyter was also responsible for one Dutch edition of Cartouche's biography. This intertextuality, with references to other narratives and literary traditions, as well as intermediality, with transmissions of the story from biography, to theatre, to epic poetry, is an important feature of these Cartouche representations. One of the cheapest intermedial adaptations that can be observed is the penny print. Before I return to the continuing history of Cartouche, let me first elaborate on this medium.

\section{Penny prints as a Dutch mass medium}

The production of Dutch penny prints began in the fifteenth century but reached its zenith in the eighteenth century. In countries like England (catch penny prints), France (imagerie populaire; feuilles volantes; images d'enfants), Germany (Bilderbogen; Fliegende Blätter) and Spain (aleluyas; pliegos de cordel), a similar genre emerged. Yet in these other countries substantial production of this specific genre started much later, 
often late into the eighteenth century or in the early nineteenth century. ${ }^{41}$ Dutch penny prints are cheap broadsides, printed on one side (30 by 42 centimetres) and illustrated with eight to twenty-four woodcuts. The penny print can be seen, with some reservations, as the precursor of the modern comic strip. Images were often produced using old or second-hand woodblocks. The rhyming captions either narrated the story or explained the pictures. ${ }^{42}$ Penny print woodcuts in the Netherlands were sloppily coloured by hand, using a brush or a leather ink ball. This method was mockingly referred to by contemporary French publishers as 'à la manière Hollandaise ${ }^{43}$ These penny prints were sold for one penny and were widely disseminated, not only via bookshops, but also by pedlars and street sellers at markets and fairs. In the nineteenth century, penny prints even arrived in primary schools, and were often distributed by schoolmasters to reward diligent and obedient pupils. Rare copies of nineteenth-century penny prints with handwritten notes prove that children actually read and used them. ${ }^{44}$

The market for penny prints in the seventeenth-century Dutch Republic grew step by step but really flourished in the eighteenth century. Therefore, the eighteenth century is often referred to as the golden age of penny prints. At this time Amsterdam was the largest production centre, but in the nineteenth century this shifted to Turnhout, a small city in the Southern Netherlands (from 1830 onwards known as Belgium).

Although there are few archival sources from the eighteenth and nineteenth centuries from which to reconstruct print runs or sales figures, some informative documents remain that provide a reliable indication of the social impact of the penny print. According to their own statistics, the Amsterdam publishing house Stichter, which specialized in popular print, sold 114,000 prints in 1789 and had doubled its sales by 1792 , to 277,000 copies. ${ }^{45}$ Taking into account that Amsterdam had about 180,000 inhabitants at the time, we get a good impression of how wide the dissemination was inside and outside of the city. At the end of the eighteenth century, a regular penny print production in the Dutch Republic averaged 250,000 prints per year. This led to an overall countrywide production of around 1 to 1.5 million penny prints annually. ${ }^{46}$ In the penny prints' boom, the Dutch Republic had about 2 million inhabitants, so this equates to at least one print per every two inhabitants each year. ${ }^{47}$ This was likely more than any other genre or category of print at the time.

For quantitative data relating to nineteenth-century penny print production, we made use of the rich and detailed statistics from the publishing house Brepols in Turnhout. Brepols produced works for the 
Southern Netherlands (Belgian) market as well as for what was then known as the Northern Netherlands (the current Netherlands). The figures discussed are breathtaking, especially when one considers that Brepols was just one (albeit dominant) market player. In 1829, 250,080 prints were sold in the (Northern) Netherlands in fifty different locations. Of that total, about 92,640 penny prints were sold in Amsterdam, 25,920 in Rotterdam, 10,560 in Den Bosch, 14,440 in Sneek and 12,480 in Bergen op Zoom. In 1857, its most successful year, Brepols sold 607,200 prints in the Netherlands (dispersed over seventeen locations) and delivered no fewer than 276,000 prints to Amsterdam. ${ }^{48}$ Nico Boerma et al. estimate that the total annual production for Belgium and the Netherlands-including prints produced for the Dutch and Belgian market in Germany and France - averaged 2.5-4 million penny prints in the first half of the nineteenth century and 6-9 million prints in the second half. ${ }^{49}$ Again, these figures help to highlight the cultural and socio-economic impact of this medium. ${ }^{50}$

Another penny print characteristic was that they covered a wide variety of topics, ranging from hagiographies, to historical events, to educational prints about animals and handicrafts. Apart from that, quack doctors, old spinsters, henpecked husbands and victims of swindles were all part of the narrative repertoire. Within this wide range of topics, fictional narratives form one specific subcategory and remain the focus of this article. ${ }^{51}$ From the seventeenth to the nineteenth centuries in the Netherlands, about sixty titles were fictional narratives. They included the adventures of famous Dutch and foreign heroes, couples and anti-heroes like Reynard the Fox, Tijl Uilenspiegel, Jan de Wasser, Klaas Kapoen, Claas Jansz and Saartje Jans, Urbanus and Isabel, Dr Faustus, Robinson Crusoe, Gulliver and the Baron of Munchhausen. Fairy tales like Little Red Riding Hood, Cinderella and Bluebeard were also remade as penny prints along with other ancient and traditional themes such as the world turned upside down and the land of Cockaigne. ${ }^{52}$ Of course, the story of Cartouche was also prominent, which begs the question: how did this typical French story end up in Dutch penny prints, and what was the function of this story in Dutch popular culture? Did it become a conformist mass-produced narrative, or did it develop into a more critical, social pamphlet?

\section{Cartouche in the world of prints}

Aside from biographies, plays and a poem, Cartouche was also produced as a hybrid textual-visual medium. The Amsterdam publisher Johannes van Leeuwen, who produced the play Cartouche of de rovers, realized that this sensational biography, which was often richly illustrated, could easily 
be enjoyed in a more visual medium. Therefore, in 1722 he produced an engraved historical print aimed at a large audience: Leven en bedryf van den berugten dief en moordenaar, Cartouche, gerecht op den 28 november 1721 ('Life and deeds of the notorious thief and murderer, Cartouche, executed on 28 November 1721') (Fig. 1). ${ }^{53}$ The print was engraved by J. C. (Jan Casper) Philips, and the accompanying text was written by Tysens. Tysens's previously mentioned 1722 translation of Cartouche, ou les Voleurs was also published by van Leeuwen and contains a publisher's advertisement announcing and promoting this illustrated version. Translated into English, it reads: 'For sale is a colourful print with the life and deeds of the notorious thief and murderer Cartouche, with clarifications in verse. ${ }^{54}$ This indicates a connection between theatre and print culture during this time. It is likely that these prints were handed out or sold as souvenirs after the play's performance. The publication of such prints of Cartouche's story appeared remarkably early in the Netherlands when compared to French prints of this kind, which were produced only 140 years later. ${ }^{55}$ Around 1860 the publishing house Pellerin in Épinal produced a Cartouche print in France for the first time.

The illustrated version depicts some key scenes from Cartouche's life, although they are not entirely similar to the imagery of the play. Instead, the print images are more closely linked to the biography. This can, of course, be viewed as an argument against the connection between print and theatre. And yet one can also argue that the appearance and circulation of these prints offered theatre-going audiences an additional perspective on Cartouche. No other characters from the play were represented in the prints. Instead, the print contained a portrait of Cartouche, a scene where he recruits gang members, scenes depicting his crimes and imprisonment, Cartouche drinking brandy with his guard, Cartouche escaping via the sewer, and, finally, his betrayal by a barking dog. In the scenes that follow, he is imprisoned again but now heavily chained. It does not end well for Cartouche, who, although he decides to confess, is broken at the wheel, and his dead body is exposed in an anatomical theatre for public dissection (Fig. 2). Importantly, in the context of the texts discussed earlier, this historical print by van Leeuwen contains an explicit and familiar moral message:

May this horrific example of Cartouche

Be a clear example to raise in your spirit

In faith, love, hope and virtues

You will observe the difference between good and bad. ${ }^{56}$ 


\section{The Adventures of Cartouche}

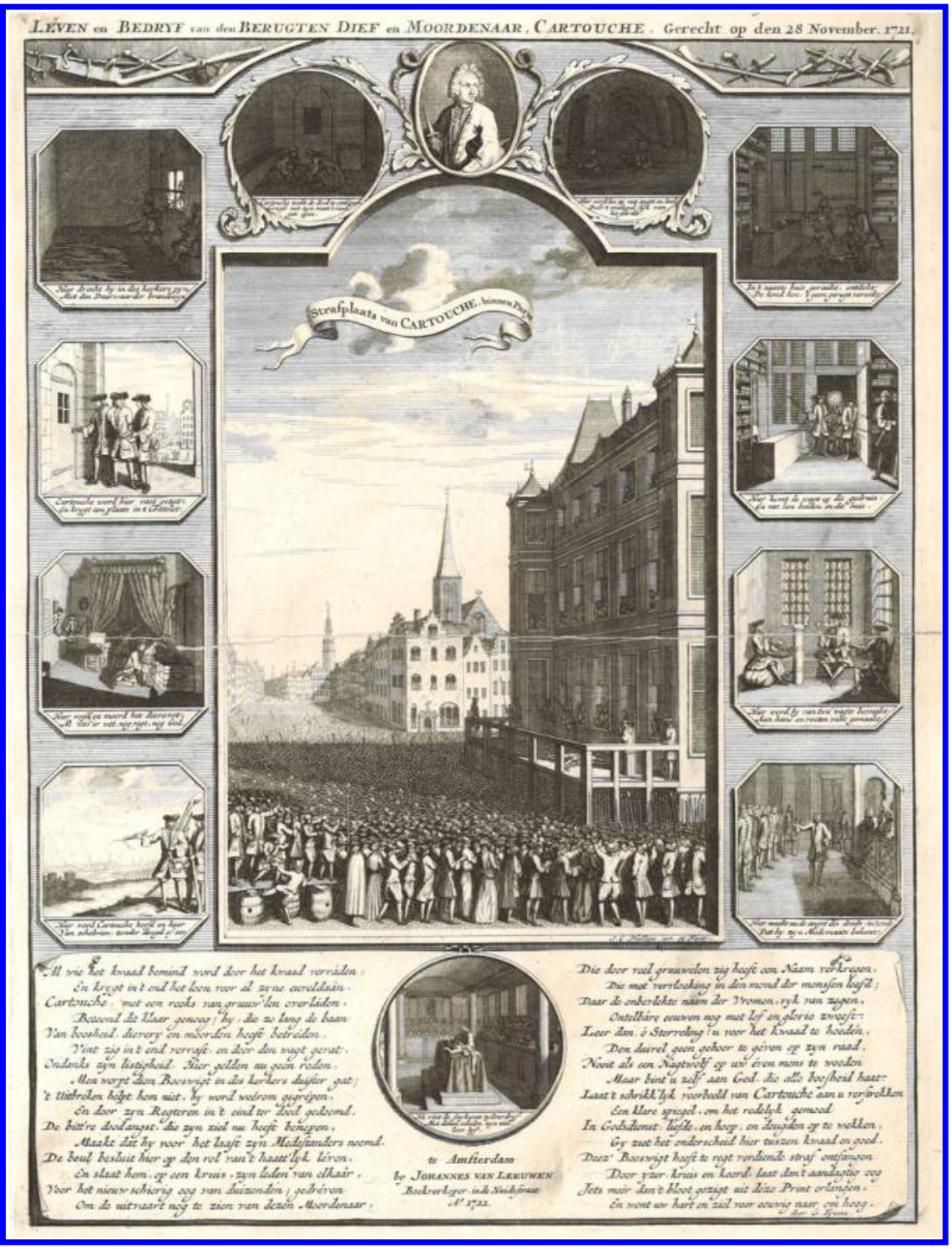

Fig. 1 History print Leven en bedryf van den berugten dief en moordenaar, Cartouche, gerecht op den 28 november 1721 [Life and deeds of the notorious thief and murderer, Cartouche, executed on 28 November 1721] Engraver Jan Casper Philips, text Gysbert Tysens (Amsterdam: Johannes van Leeuwen, 1722). Maritime Museum Rotterdam. 


\section{Cultural History}

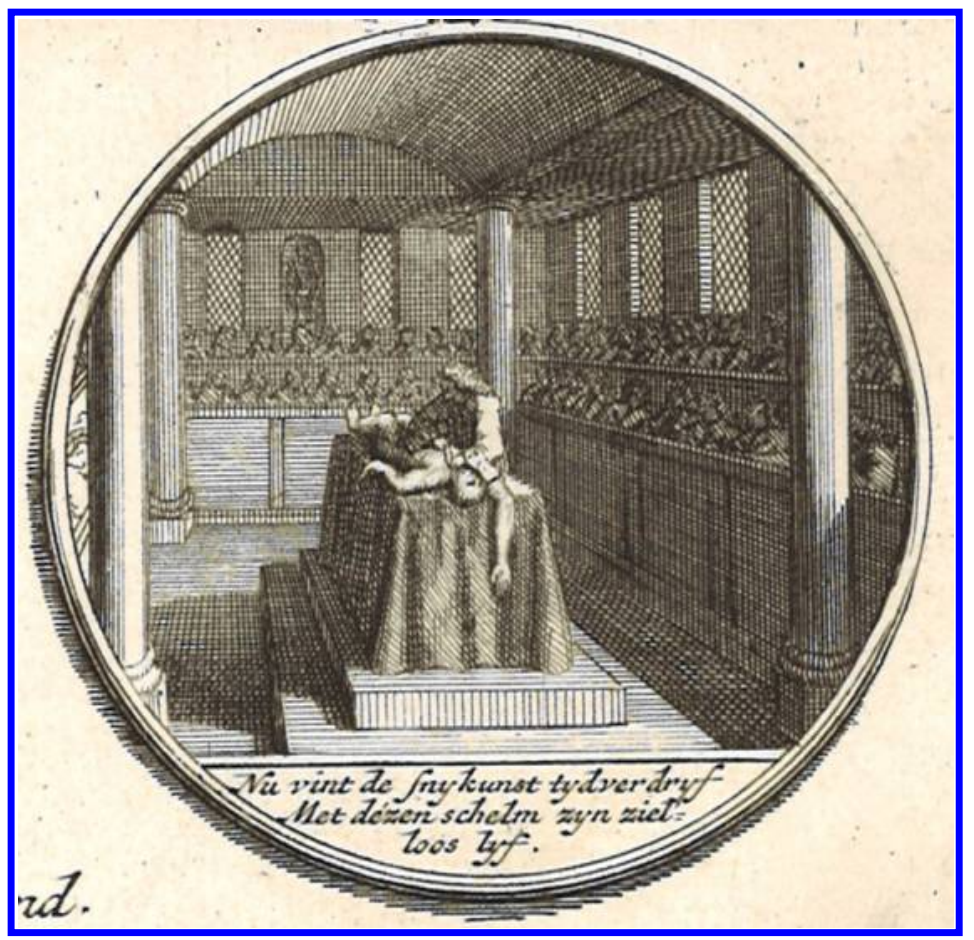

Fig. 2 Detail, public dissection Cartouche.

It seems likely that van Leeuwen's print initiative stimulated the production of even cheaper print versions about the criminal Cartouche. Soon the Dutch market was flooded with penny prints containing similar material. According to Boerma et al., no fewer than fourteen penny prints about Cartouche have been preserved; they were printed by a minimum of fifteen Dutch publishers. ${ }^{57}$

The Dutch penny print about Cartouche was produced from the 1730s onwards by Isaac van der Putte (1723-48) and Joannes Kannewet (1723-80). This edition (no. 68) ${ }^{58}$ was later copied by the publisher Ratelband-Bouwer (1782-93) (Fig. 3). The title is very straightforward: Het leven en snoot bedrijf, Gevangenis en Dood, van Cartouche te Parijs ('The life and evil deeds, imprisonment and death of Cartouche in Paris'). This print - an extended version of the history printed by van Leeuwen - presents the main facts about Cartouche's life and frequently refers to the original French biography. It reveals how Cartouche became a gang leader, how he mercilessly stole and killed, how he was betrayed and how he ended up in prison. It also illustrates his attempted escape and his ultimate discovery via the barking of a dog. 


\section{The Adventures of Cartouche}

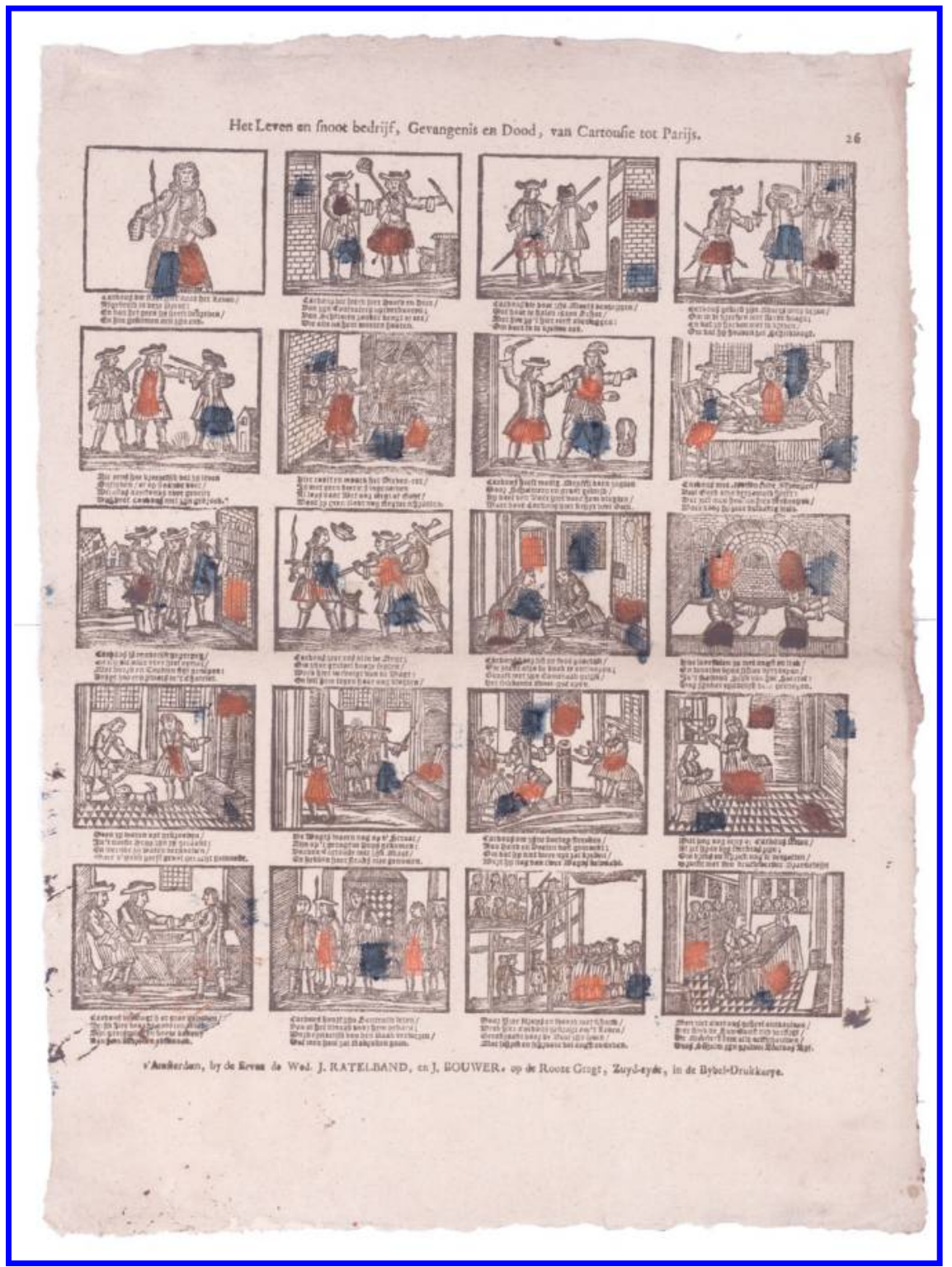

Fig. 3 Penny print: Het Leven en snoot bedrijf, Gevangenis en Dood, van Cartousie tot Parijs [The life and evil deeds, prison and death of Cartouche in Paris], (no. 26), (Amsterdam: Erven Wed. J. Ratelband en J. Bouwer, c. 1778-1793). Special Collections, University of Amsterdam. 


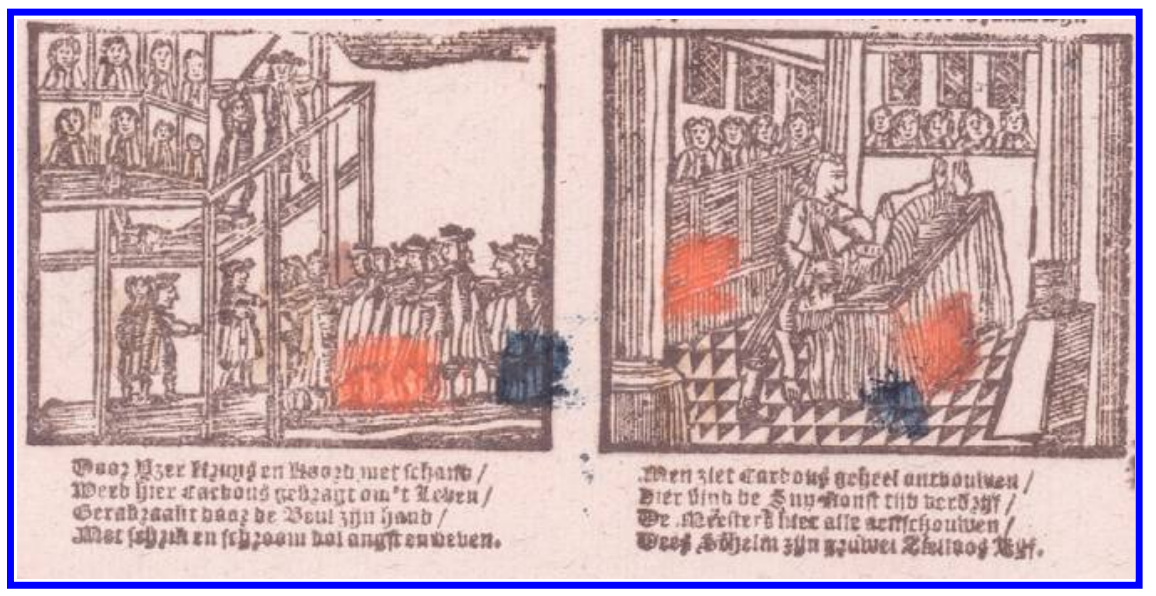

Fig. 4 Detail, execution and dissection of Cartouche.

After Cartouche is taken to the scaffold, broken on the wheel and executed, his corpse is used for anatomical dissections (Fig. 4). Although Cartouche's deeds were visualized with a flavour of admiration and sensation, he was, without any consideration of his motives or background, explicitly condemned as an incurable criminal. This first Dutch penny print was certainly not a direct adaptation of the more engaged French biography Histoire de la vie from 1721. The social criticism in the biography with regard to the ignored veterans of the War of the Spanish Succession (such as Cartouche) was, for instance, left out.

Another penny print, with the title Het Leven en Bedryf van Cartouche ('Life and deeds of Cartouche'), was published by the widow of Jacobus van Egmont (Amsterdam, 1761-1804) in the second half of the eighteenth century (Fig. 5). This print is very similar to the engraved print made by van Leeuwen. The images and text captions are practically identical to those in the earlier penny print of Van der Putte and Kannewet (no. 68). Yet in the van Egmont print, Cartouche ultimately shows remorse and confesses, whereas this scene is totally absent in van der Putte and Kannewet print. Also, the moralistic verse from van Leeuwen's engraving is not reproduced in the penny print, most likely because it did not fit in this cheaper format.

In the history of this story and the two penny prints discussed here, Cartouche's life and deeds were described with a certain amount of admiration and sensation. In the end, however, the criminal was condemned and considered rightly executed. My research shows no trace of social protest, or even of a certain understanding of or compassion for Cartouche's fate, as was present in the biography and 
The Adventures of Cartouche

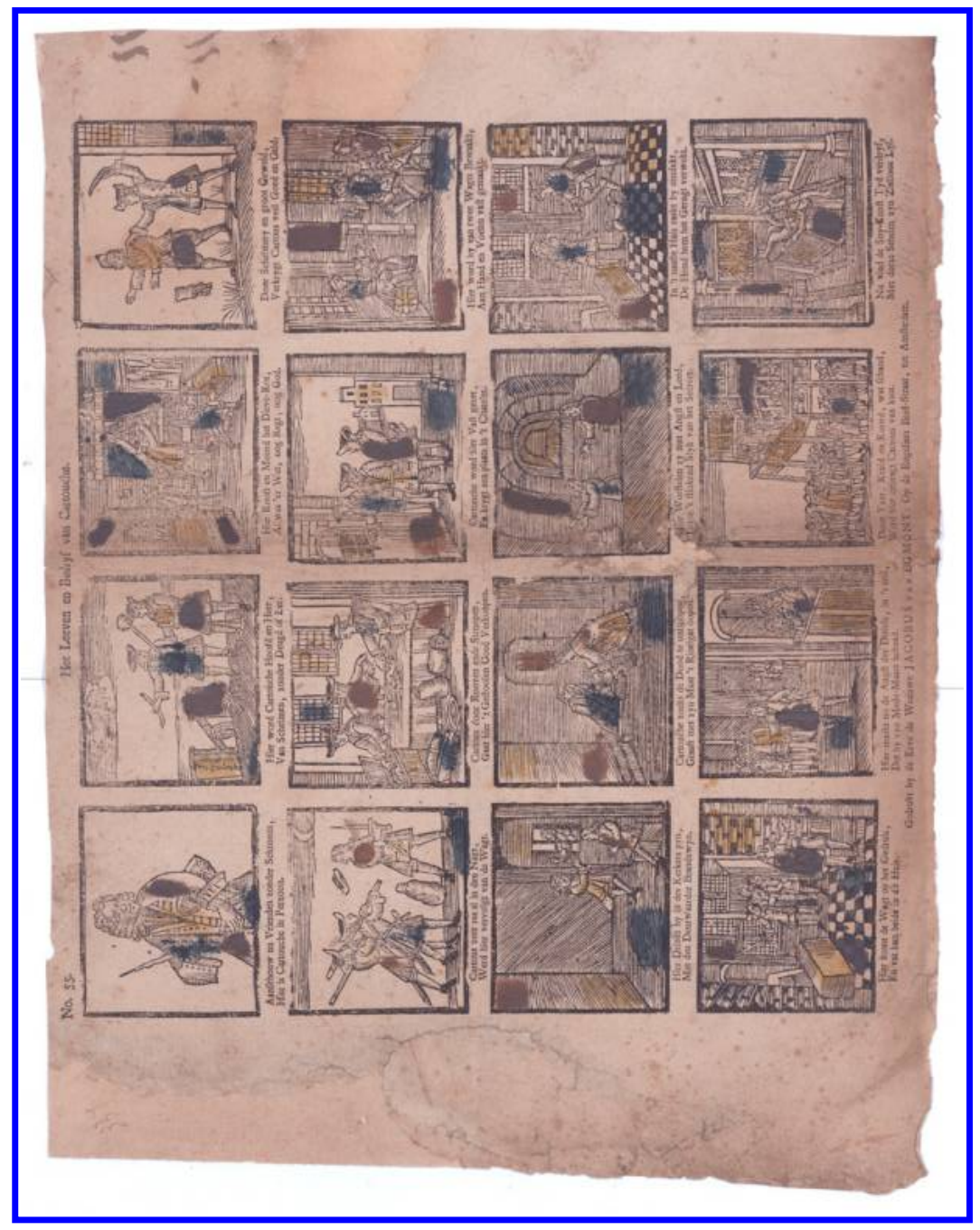

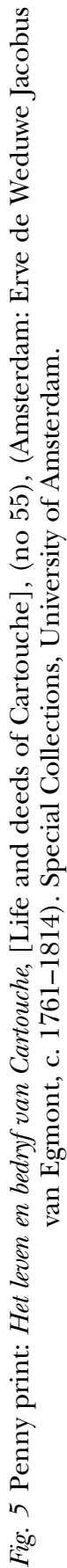


the plays. Egmond has stated that less expensive material is always more negative and more conformist than less widespread genres. This seems indeed true for the penny prints when we look only at the content. But when we take into account the context, function and appropriation of this material during the late eighteenth and nineteenth centuries, we come to a different conclusion.

\section{A new audience and an edifying spirit}

At the end of the eighteenth century, a third version of the story was published in a penny print by the Stichter's Heirs publishing house in Amsterdam (1775-1813). This version targeted children as the primary audience. This event represented a more general and decisive turning point in the history of penny prints: children were now considered an important segment of the popular market. The rise of children's literature coincided with the foundation of the Society for Common Benefit in the Dutch Republic in 1784. This enlightened, civilizing, upper-middle-class society aimed to transform indecent popular stories and prints into edifying and informative children's books.

In examining these 'edifying' Cartouche adaptations for children, however, one witnesses a strange metamorphosis: Cartouche slowly became the German bandit Schinderhannes. The publisher Stichter used the same woodblocks as van Egmont - although no copy of the van Egmont Cartouche penny print is left - to portray Schinderhannes. In other words, the printer changed the title but printed the same story of Cartouche. The moral intentions are clear from the title: Deez'printjes, lieve Kindren, zyn niet geschikt tot vreugd, / Maar om u voor te lichten op't smalle pad der deugd ('These prints, sweet children, are not for entertainment, but to guide you on the narrow path of virtuousness'). The same portrait used to depict Cartouche is now captioned with the following text: 'Dit 's Schinderhannis die veel gruwlen heeft bedreven / Op Duitschen bodem deed hy ieder voor hem beven' ('This is Schinderhannes, who has committed many atrocities / on German soil he made everyone shiver with fear') (Fig. 6). The flexible relationship between image and caption is also clear in the scene where Cartouche attempts to escape via the sewer. In the Schinderhannes version, this caption simply refers to the chained bandit as growing fearful given his approaching execution. After Stichter, the publisher Noman reproduced this hybrid Cartouche/Schinderhannes penny print. ${ }^{59}$

Schinderhannes (whose real name was Johannes Bückler) was born in 1779 and thus lived much later than Cartouche. Yet their lives share many similarities. Schinderhannes was the leader of a criminal gang in the Rhineland which was notorious for armed robbery, horse stealing, 
The Adventures of Cartouche

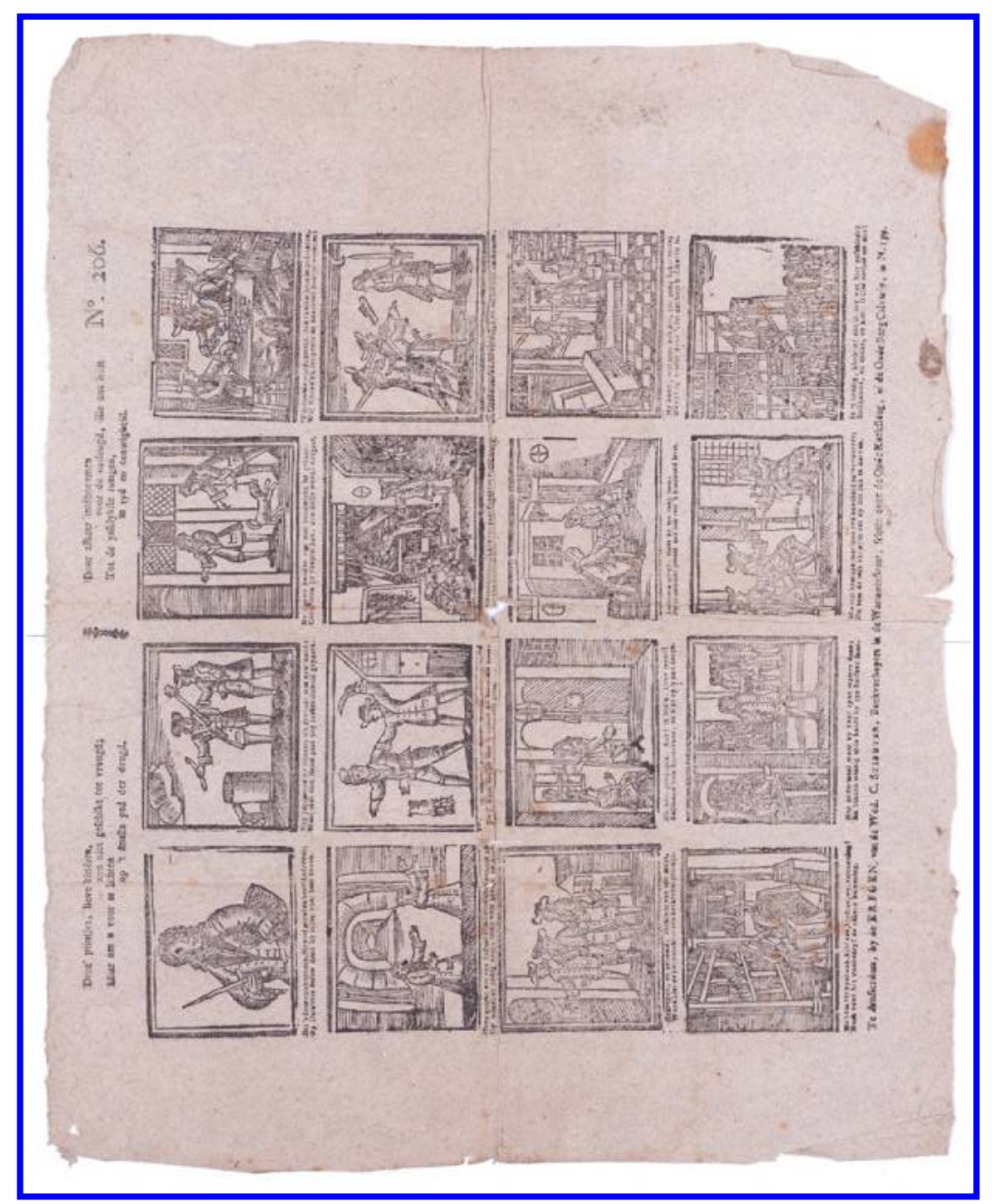

ธุ

닐

ริ

ఏ

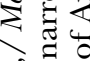

की

ป

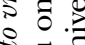

$\stackrel{2}{\circ} 5$

$\approx$

$\overleftarrow{0}$

a 00

ฐ

ฐ

그는

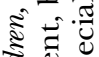

¿્ટ ڤ

$\forall \Xi$

เ สิ

:

है

离

ఏ 드

एँ

๑ั

تี ฮี

द्वे

츨

氙寻

$= \pm$

苋管

ค क त

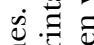

छ

컹되

ฮี

튱

힝

๘

은

芯

능

\& ¿

บै $\approx$

० है

ปี

$6:$

si 
highway robbery and extortion. He was executed, together with nineteen accomplices, after having committed horrific crimes. The actual execution method differed from that used for Cartouche and was more humane according to the standards of the time. Schinderhannes was publicly beheaded on the French guillotine on 21 November 1803. Soon after his death, his fame spread rapidly via the public and popular press. Even nowadays Schinderhannes is known as a historic villain and viewed as a folk hero in Germany and elsewhere in Europe. ${ }^{60}$

Despite all the crime and physical violence in the story of Cartouche or Schinderhannes, it is interesting that the leaders of the Society for Common Benefit did not consider it inappropriate for children. They likely acknowledged the immense popularity of the story and just asked Stichter to create a more decent and child-friendly version. What resulted contained more explicit moral and religious messages. For instance, as Schinderhannes awaits execution in his cell, the caption of the children's version reads, 'Watch this great villain. $\mathrm{O}$, sweet children, aren't you horrified?!'

Alas, the story of Cartouche simply proved too powerful and popular to be completely erased from the cultural repertoire of the lower classes. Civilizing institutions tried to implement their cultural ideology through such prints, but despite the addition of moral lessons, the popular visualization of the heroes Cartouche and Schinderhannes still aroused admiration amongst their readership. Using Fiske's terminology, we could define this public appropriation of Cartouche as a manifestation of evasion.

\section{The Belgian connection}

In the nineteenth century, the production of Dutch penny prints moved to Turnhout, a small city in the Southern Netherlands, which was briefly part of the Kingdom of the Netherlands until 1830, when both the Northern and Southern Netherlands formed the Kingdom of Belgium. The print publishers Brepols (1817-33) (penny print no. 56) and later Glenisson \& Van Genechten (1833-56) (penny print no. 17) and Beersmans (1866-97) (penny print no. 48) created their own versions of the Cartouche story, which differed slightly from the eighteenth-century versions. ${ }^{61}$ These later adaptations were true children's stories that contained an obvious moral. The Beersmans edition (no. 48) begins:

Dear children, let the bloodthirst and evilness

of this criminal, impress on your memory.

Despise Cartouche in your heart for ever, and always stay virtuous and pious. ${ }^{62}$ 
And yet elements of social protest and the image of Cartouche as a womanizer returned in these Belgian versions. For example, in these versions Cartouche gave some of the gold to the poor and took a lady out riding in his carriage (Fig. 7). According to Cartouche's biography, he indeed had a turbulent love life while supporting three mistresses and several children. It was known that when he was in prison, several high-class women regularly visited his cell. These stories also conveyed a more critical message because the lady he took for a ride later betrayed Cartouche. Also, some other new scenes were added to the story - such as the robbery of a stagecoach and a trick with an exchange letter - that were not present in the eighteenth-century prints. I believe that these Belgian versions breathe new life into the atmosphere of the 1722 biography of Cartouche. They also prove that the earlier turning point around 1750, when the social bandit and highwayman lost their moral agency, was not irreversible.

Yet one is left wondering why this change occurred. Quite frequently, Brepols and other Belgian publishers bought and used the same woodblocks as their colleagues from the Northern Netherlands. In this case, however, it is possible that Brepols had more affinity with the French tradition of Cartouche rather than the Dutch. I especially suspect this may be the case given the growing tension between the Dutch King William I and the Southern Netherlands at the time. Soon this led to a military conflict and a final separation of the two countries. This is worth mentioning given that Brepols targeted both the French and Walloon markets, producing bilingual (Dutch and French) captions in their penny prints.

\section{Conclusion}

In conclusion, the French hero Cartouche was adapted to Dutch and Belgian popular culture in the eighteenth and nineteenth centuries with great success. This occurred in different media and led to multiple editions, adaptations and adjustments. However, the penny prints about Cartouche - more than any other genre - spread the story through all layers of society. In doing so, over such a long period of time, they helped root the hero Cartouche in the Dutch collective memory.

What is remarkable about the publication history of Cartouche's story in the Netherlands is that it shifted so early in the eighteenth century to the mass medium of the penny print. This can probably be attributed to two reasons. Firstly, in the Dutch Republic during this period, the penny print was already an important secular genre that popularized farces and folk heroes like Till Eulenspiegel. Given the speedy translation and printing of the biography and the comedy in the Netherlands, the story 


\section{Cultural History}

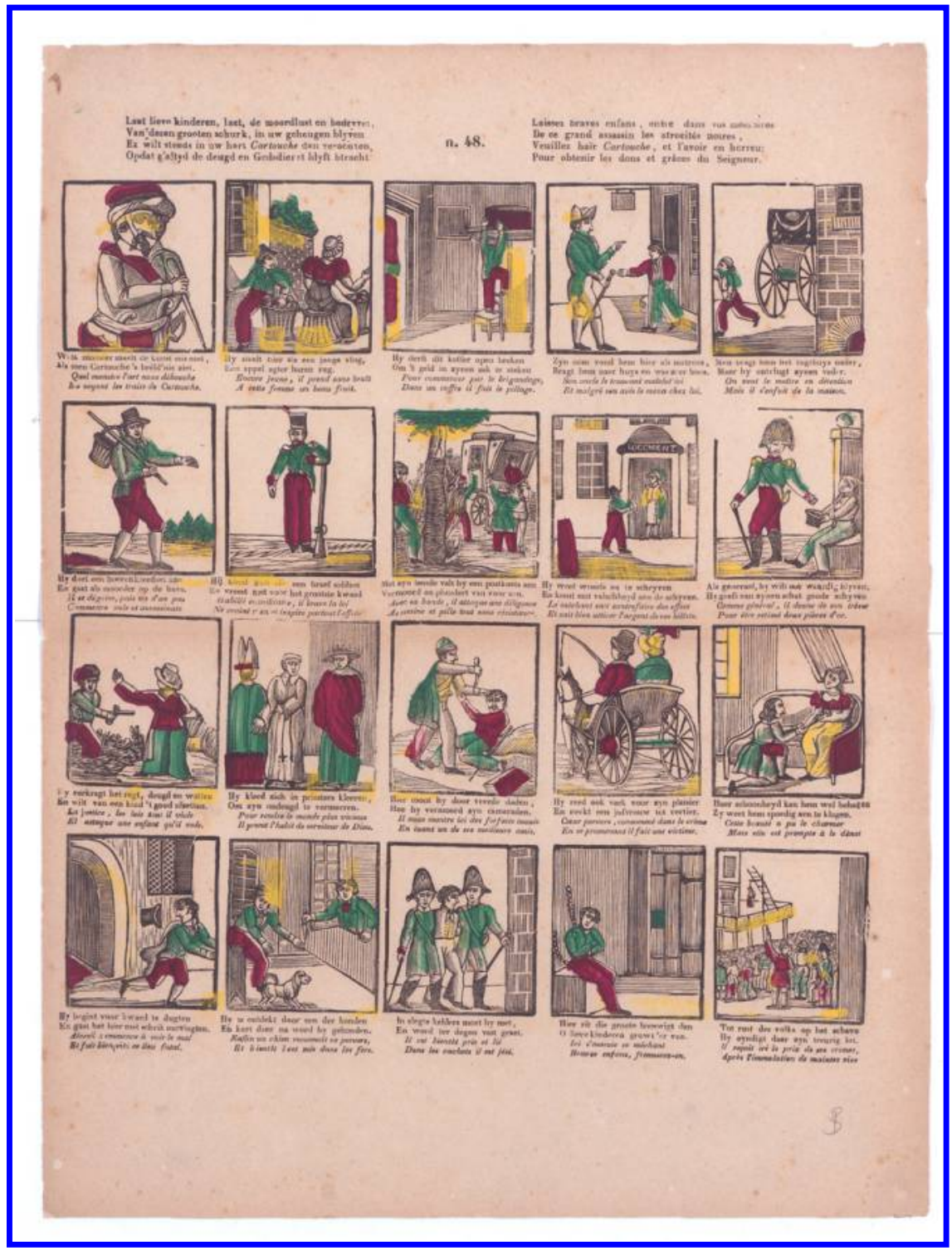

Fig. 7 Penny print: Laet lieve kinderen, laet, de moordlust en bedrijuen, Van desen grooten schurk, in uw geheugen blyven [Dear children, let the blood thirst and evilness of this criminal, impress on your memory] (no 48) (Turnhout, Fr. A. Beersmans, c. 1866-1879). Special Collections, University of Amsterdam. 
of Cartouche was already available in the Dutch Republic. What is more, the biography published in the Netherlands was richly illustrated. Additionally, the publisher Johannes van Leeuwen - also known for translating and publishing the Cartouche comedy-came out with an engraved print intended for a wide audience. Given that textual and visual representations of Cartouche were so abundantly available, printers of popular material such as the penny print could easily profit from this by producing their own cheap versions of this story.

In subsequent printings and media, the story of Cartouche was adapted, owing largely to the new societal contexts in which it appeared. During the popularity of Cartouche, the Dutch Republic was not ruled by an absolutistic regime, did not have a strong aristocratic tradition, was a highly urbanized country and had developed a system of urban welfare. This implies that the social element - an anti-establishment attitude and the involvement of higher-class ladies - did not have much appeal for ordinary people. In this sense, Egmond was right about popular genres being socially less critical and more negative about the villain. Alternately, social protest and political discourse could have been considered more suitable for pamphlet literature, libels and other periodicals. Still, Fiske, Jenkins and McKenzie have valid points when they state that the audience of penny prints or other cheap material like dying speeches, to a large extent, could bend the story to their will. The result was that Dutch penny prints resisted the pressure of the civilizing Society of Common Benefit and that this Society could not erase the story from the popular repertoire.

To return to the discussion between Hobsbawm and Blok on social banditism, the Dutch adaptation and popularization of Cartouche have more to do with fictionalization and myth creation (Blok) than with social reality (Hobsbawm). That is also the reason that Cartouche was merged with the German villain Schinderhannes and the Amsterdam criminal Jacob Frederik Muller, alias Jaco (1690-1718). ${ }^{63}$ These stories catered to the growing demand for fictional criminal biographies. Of course, the lower and middle classes could identify with these antisocial heroes, but the message conveyed did not lead to social resistance or protest against the political system. In England as well as in the Dutch Republic, we can observe a decreasing role of the gentleman robber as a social critic. This more depreciating image also manifested itself in moralistic and pedagogic penny prints that were incorporated into the new subfield of children's literature.

Still, this development was reversed again in the nineteenth century, when Brepols began producing the story of Cartouche in Belgium. Although the story told in Belgium still had a strong moral flavour, and 


\section{Cultural History}

stressed Cartouche's evilness from a young age, the more ambivalent side of his biography was once again brought to life. The Belgian penny prints are not as critical of the ruling powers as the 1722 biography (Histoire de la vie et du process du fameux Louis-Dominique Cartouche) and the 1721 play (Cartouche, ou l' Homme imprenable), but they still praised Cartouche for assisting the lower classes and stressed the deceitfulness of the higher classes. Furthermore, exposing Cartouche's love life was viewed as making him more human. This version of the story was clearly the source for twentieth-century films like Cartouche (1962), directed by Philippe de Broca, with Jean-Paul Belmondo and Claudia Cardinale as the main characters. ${ }^{64}$

Through a close examination of the publication history of the story of Cartouche, this article has proved that the popularization process characteristic of penny prints was neither linear nor one-dimensional. Contrary to what is often stated in historical studies, the production and reception of Cartouche-related cheap prints proceeded in a more dynamic, cyclical and often also ambiguous fashion. The Dutch penny prints were a cultural treasure house, filled with popular stories of villains, heroes, saints, princesses and jesters that could be activated and transformed any time writers, publishers and readers needed to. They represent the conformism of mass culture as well as the dynamics of popular culture.

\section{Notes}

1. As a source of inspiration, I refer to a recent study in the field of popular literature: Joad Raymond (ed.), The Oxford History of Popular Print Culture, vol. 1: Cheap Print in Britain and Ireland to 1660 (Oxford: Oxford University Press, 2011).

2. E.g. James. A. Sharpe, "Last Dying Speeches": Religion, Ideology and Public Execution in Seventeenth-Century England', Past and Present, 107 (1985), pp. 144-67; Florike Egmond, 'The Noble and the Ignoble Bandit: Changing Literary Representations of West-European Robbers', Ethnologia Europaea: Revue internationale d'ethnologie européenne = Journal of European Ethnology, 17:2 (1987), pp. 139-56; and Patricia Vansummeren, Kinderprenten van Brepols (Turnhout: Brepols, 1996).

3. E.g. Jason Peacey, Politicians and Pamphleteers: Propaganda during the English Civil Wars and Interregnum (Aldershot: Ashgate, 2004).

4. Henry Jenkins, Convergence Culture: Where Old and New Media Collide (New York: New York University Press, 2006).

5. John Fiske, Understanding Popular Culture (Boston: Unwin Hyman, 1989).

6. Roeland Harms, 'Popular Culture and Penny Prints: How Eighteenth- and Nineteenth-Century Readers in the Dutch Republic Indirectly Created Their Own Narratives', Cultural and Social History, 12:2 (2015), pp. 217-34.

7. Peter Linebaugh, The London Hanged: Crime and Civil Society in the Eighteenth Century (London: Penguin Books, 1993); and Andrea McKenzie, 'The Real Macheath: Social Satire, Appropriation, and Eighteenth-Century Criminal Biography', Huntington Library Quarterly, 69:4 (2006), pp. 581-605. 


\section{The Adventures of Cartouche}

8. Some studies about the French tradition: Hans-Jürgen Lüsebrink, Kriminalität und Literatur im Frankreich des 18. Jahrhunderts: Literarische Formen, soziale Funktionen und Wissenskonstituenten im Zeitalter der Aufklärung (Munich: Oldenbourg, 1983); and Lise Andries (ed.), Cartouche, Mandrin et autres brigands du XVIIIe siècle (Paris: Editions Desjonquères, 2010). For the German field of research: Daniel Bellingradt, 'Der wiederverwertbare Räuberhauptmann: Oder: Wie kam der Räuber in den Kalender der Frühen Neuzeit?', in Klaus-Dieter Herbst (ed.), Astronomie, Literatur, Volksaufklärung: Der Schreibkalender der Frühen Neuzeit mit seinen Text- und Bildbeigaben (Bremen: Edition Lumière, 2012), pp. 413-30.

9. Linebaugh, London Hanged; and McKenzie, 'Real Macheath'.

10. Fiske, Understanding Popular Culture, pp. 26-32.

11. Ibid. pp. 32-47.

12. Jenkins, Convergence Culture, p. 2.

13. Ibid. pp. 2-3.

14. Eric J. Hobsbawm, Bandits (New York: Penguin Books, 1972); Eric J. Hobsbawm, 'Social Bandits: Reply', Comparative Studies in Society and History, 14:4 (1972), pp. 503-5; Anton Blok, 'The Peasant and the Brigand: Social Banditry Reconsidered', Comparative Studies in Society and History, 14:4 (1972), pp. 494-503; and Egmond, 'The Noble and the Ignoble Bandit'; McKenzie, 'The Real Macheath'.

15. Hobsbawm, Bandits, pp. 127-8.

16. Blok, 'The Peasant and the Brigand', p. 498.

17. Hobsbawm, 'Social Bandits', p. 504.

18. Ibid. p. 505.

19. Egmond, 'The Noble and the Ignoble Bandit'.

20. Ibid. p. 141.

21. Ibid. p. 144.

22. Lincoln B. Faller, Crime and Defoe: A New Kind of Writing (Cambridge: Cambridge University Press, 1993), pp. 1-5; Linebaugh, London Hanged; and McKenzie, 'Real Macheath', pp. 583-4.

23. McKenzie, 'Real Macheath', pp. 583-4, 591-2.

24. Histoire de la vie et du procès du fameux Louis Dominique Cartouche et de plusieurs de ses complices (Lille : Henry, 1722).

25. Piet J. Buijnsters, Levens van beruchte personen: Over de criminele biografie in Nederland gedurende de $18^{e}$ eeuw (Utrecht: HES-publishers, 1980).

26. See, for instance, the story of Jack Sheppard the 'gaol-breaker'. Linebaugh, London Hanged, pp. 7-41; and McKenzie, 'Real Macheath', p. 586.

27. Again this episode is similar to the story of the imprisoned Sheppard, who, in the words of Linebaugh, was visited by the 'great, the fast, the strong, the talented and the beautiful'. Linebaugh, London Hanged, p. 33.

28. 't Leven van den wereldberuchten kapitein der moordenaren Louis Dominique de Cartouche (Delft: Reinier Boitet, 1722) (a copy can be found at the Special Collections of the University of Amsterdam: O 62-8272), pp. 117-8.

29. 't Leven van den wereldberuchten kapitein der moordenaren Louis Dominique de Cartouche, p. 117

30. McKenzie, 'Real Macheath', pp. 583-6.

31. 't Leven van den wereldberuchten kapitein der moordenaren Louis Dominique de Cartouche.

32. The biography was published in Amsterdam by: Johannes de Ruyter (2nd edition, 1731), Willem van Egmont (3rd edition, c. 1730s) and Geertrui de Ruyter/ Johannes de Ruyter (4th edition, 1735), in Dordrecht by Hendrik (I) Walpot 


\section{Cultural History}

(5th edition, 1743), in Amsterdam by D. Weege and A. Cornelis (6th edition, second half of the eighteenth century), in Amsterdam by Barend Koene (1773), in Amsterdam by Abraham Cornelis (9th edition, 1774), in Amsterdam by A. Goejet and erven A. Cornelis bookseller (10th edition, 1787), and in Amsterdam by S. and W. Koene (1787). Information retrieved from the stcn (short-title catalogue Netherlands) (June 2015).

33. 't Leven van den waereld-beruchten kapitein der moordenaaren: Louis Dominique de Cartouche (Amsterdam: Barent Koene, 1773), located in National Library The Hague 28 A 31, fols. A3v-A4r.

34. McKenzie, 'Real Macheath', p. 598.

35. De schelmeryen van Cartouche (Amsterdam: Willem Barents, 1722). I used the copy of the University Library Leiden: 1094 G 14: 1.

36. I used a copy from the Bayerische Staatsbibliothek in Munich.

37. For sale were 'Allerhande soorten van Heilighen' ('All sorts of penny prints').

38. Pieter Langendyk, De bedriegery van Cartouche, of de Fransche roovers: Blyspel (Amsterdam: David Ruaris, 1732). I used the copy found in the University Library Leiden 1094 D 3: 1 .

39. Arlequinus Cartouche (Antwerp: Joannes Paulus Robyns, 1722); and Arlequin Cartouche (Augsburg: Johann Christoph Kolb, 1722). See also Egmond, 'The Noble and the Ignoble Bandit', p. 140.

40. Nicolas Racot de Grandval, Cartouche, ou le vice puni (Paris : P. Prault, 1725).

41. Jean Mistler et al., Épinal et l'imagerie populaire (Paris: Hachette, 1961); Paul Stephen Falla and Susan Lambert, French Popular Imagery: Five Centuries of Prints (London: Arts Council of Great Britain, 1974); Thomas Gretton, Murders and Morality: English Catchpenny Prints 1800-1860 (London: British Museum Publications, 1980); Elke Hilscher, Die Bilderbogen im 19. Jahrhundert (Munich: Verlag Dokumentation, 1977); and Joaquim Marco, Literatura popular en España en los siglos XVIII y XIX: Una aproximación a los pliegos de cordel (Madrid: Taurus, 1977).

42. N. Boerma et al., Kinderprenten, volksprenten, centsprenten, schoolprenten. Populaire grafiek in de Nederlanden 1650-1950. (Nijmegen: Vantilt, 2014] and Jeroen Salman et al., Sterke verhalen: Viff eeuwen vertelcultuur (Nijmegen: Vantilt, 2014).

43. Boerma et al., Kinderprenten, p. 66.

44. Boerma et al., Kinderprenten, pp. 106-12.

45. City Archive Amsterdam, 'Boekverkopersboeken van de Erven Stichter 1787-1792', Toegang 5060, Koopmansboeken, inv. no 185.4. This information comes from the yet unfinished dissertation of Talitha Verheij, Verhalen in beeld. Het verschijnen en verdwijnen van het beeldverhaal tussen 1700-1900 (Utrecht [2018]), one of the members of the Utrecht research project 'Popularisation and Media Strategies in the Netherlands (1700-1900). The author was project leader of this project.

46. Boerma et al., Kinderprenten, p. 76.

47. Jan de Vries and Ad van der Woude, Nederland 1500-1815: De eerste ronde van economische groei (Amsterdam: Balans, 1995), p. 96.

48. Vansummeren, Kinderprenten van Brepols, p. 195.

49. Boerma et al., Kinderprenten, pp. 75-7. The average print run of a title around 1850 was likely 12,000 in order to make the production profitable. However, print runs of 20,000-25,000 were also quite common in this period.

50. In England eighteenth-century criminal pamphlets and broadsides were aimed at the 'middling sort' rather than the working class. They had a similar format as newspapers and novels. McKenzie, 'Real Macheath', p. 591. 


\section{The Adventures of Cartouche}

51. This genre is studied in the aforementioned Dutch research project Popularisation and Media Strategies.

52. Salman et al., Sterke verhalen.

53. The only known copy of this print is preserved in the Maritime Museum in Rotterdam.

54. In Dutch: 'Bij den drukker dezes is gedrukt en te bekomen in een keurelyke [sic] Printverbeelding, 't Leeven en Bedryf van den berugten Dief en Moordenaar Cartouche, met verklaringen in Poezy.'

55. Marie-Dominique Leclerc, 'Représentation de Cartouche et Mandrin: De la bibliothèque bleue à l'imagerie populaire, Deux héros typés', in Alberto Milano (ed.), Generals and Beggars, Actors and Sovereigns: Portraits in Widely Circulated Prints from XVII to XX Century (Bassano del Grappa: Tassotti Editore, 2013), pp. 267-73.

56. In Dutch: 'Laat 't schrik'klyk voorbeeld van Cartouche aan u verstrekken / Een klare spiegel om het redelyk gemoed. / In Godsdienst, liefde, hoop en deugden op te wekken / Gy ziet het onderscheid hier tuszen kwaad en goed.'. Quote from the aforementioned engraving Leven en bedryf van den berugten dief en moordenaar, Cartouche, gerecht op den 28 november 1721.

57. Boerma et al., Kinderprenten, pp. 380-382, 860. Noman made two editions.

58. Publishers numbered their series of prints. It is a useful tool for booksellers to distinguish the different titles.

59. Boerma et al., Kinderprenten, pp. 234-8, 381.

60. Hobsbawm, Bandits, p. 20. In the Dutch city of Roermond, located in the south-eastern province of Limburg, up until today they hold an annual performance of the Schinderhannes light opera. See www.schinderhannes.nl.

61. Boerma et al., Kinderprenten, pp. 380-2.

62. Het Leven en bedrijf van Cartouche (Turnhout, Fr. A. Beersmans, (between 1866-1879), no. 48$)$.

63. Boerma et al., Kinderprenten, pp. 380-1.

64. Cartouche, film, directed by Philippe de Broca (Les Films Ariane, 1962). 